\title{
最新のストリーク筋検出技術
}

\author{
株式会社ヒューテック 開発部 杉 野 欣 伸
}

\section{The Latest Technology of Detecting Streaky Flaws}

\section{Yoshinobu Sugino}

Research and Development Dept., Futec Inc.

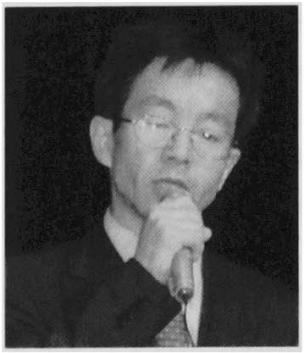

As has been the case, many requirements are made to the inspection system. Even more diversified requirements are seen because of its possible versatile applications. There are some industries in which, a short while back, it was thought to be hard to apply automatic inspection, but now because of more increased competition, some kind of automatic inspection would be a most effective means to be apart from the other competitors. The competition is not only among domestic but world-wide and is by all means intensifying.

As to the overall performance, there are two critical points in focus. The first is how to most effectively utilize the flaw data for the improvement of product quality and production yield. The inspection system was once regarded as a simple sensor, but the times have changed now and is required to provide an opportunity to becoming more competitive position in the market. The collected data is thought to be even more valuable if it were shared among operators via network. It would be further processed. like $\mathrm{SQC}$ analysis, to bring in more benefit.

The second is, needless to say, the sensitivity itself. Market is going to require defects detected which were used to be not required before. The more sensitive means, more data is gathered.

It is crucial to make the system more efficient in handling vast flaw data along with improved sensitivity. On top, how to most effectively share that flaw data internally in order to achieve the better result.

Here I describe briefly about how we can achieve the afore-mentioned balanced performance.

分類： $V_{3}$ 紙パルブ工程計器およびセンサ, $V_{1}$ 計装・制御システム一般

\section{1.はじめに}

今までもそうであったようにこれからも検査システ ムへの要求は多種多様であり, 要求の数もますます增 えていくと思われる。また，従来検査システムを必要 としていなかった業界へも拡がりを見せており，気が 付けば周辺のどの業界も最新の検査システムが林立し
ているという状態になりかねません。この状態は, 日 本の製造業が他と差別化をして生き残るためにさけて は通れないものと判断します。この環境下，各業界に おいて扮客様から検查システムに求められる要求内容 としては，大きく下記の 2 点がクローズアッブされて いる。一つは検査システムのデータの有効利用です。 過去に遡ってみると, 検査システムは検査機であり単 
なるセンサーに置き替わるものとして利用されていた。 しかし，お客様の製品の品質が急速に高くなっていく という環境のなか，検出したデータをどのように利用 すれば品質保証が十分になされ，かつ生産の効率が上 がるか，さらには品質の向上に熬がるかが模索され始 めている。ネットワークによるデータの加工・共用化 がデータの有効利用の兆しである。また，もう一つク ローズアップされているのは当然ながら検出性能であ り，簡単にいえば従来の検查機で検出できなかったも のも検出するということである。この検出性能が向上 することは前速のデータの加工・共用化にも大きく影 弊がありバランスのとれた検査システムには不可欠で ある。本報ではこの検出性能を向上させるための技術 を記述する。

\section{2. 紙パ業界が品質・歩留まり向上に抱える 課題と求められる技術}

秖パルブ莱界の原反から一般消費者までの生産の流 れにおける位置はかなり上流の業界ということになる。 この場合, 当然ながら下流の工程ほど製品の付加価値 が高くなるわけで, クレームを起こした場合の保証も 場合によっては大きなタメージとなる。また，下流業 界の品質に関する動向も影箘する。例えば様々な市場 における検查機の此㶳が高くなってきているというこ とも，それら市場がとのような検查機を使用している のかということも影䇺するだろうし，下流大手メーカ 一の品質トラフルも当然大きく影箘する。この下流の 羓界の品質動向は贯気によっても大きく左右される。 どの羓界も不景気なとき任と検查の人員を投入し，歩 留りをあげようとする。このため品質保証のレベルが 辟しくなってくる。

これとは別に，工程の条件による不利な点も上げら れる。紙パ業界は大きなマシンで早く巻いて生産効率 を上げているが，下流の工程はラインスピードが遅く， 検査幅も狭いため, 安価で高性能な検査が実現しやす い。現状弊社が納入している例を表 1 に提示する。

以上のような品質保証上の条件を抱え，具体的には
下記のような具体的品質トラブルがある。当然これら は検査機メーカーの目で判断した物のみである。

(1) 穴

(2) 污れ

(3) 虫

(4) しわ

(5) 耳破れ

(6) スジ

これらが代表的な欠陥であるが, 検出困難な欠陥と いえば 6 番目のスジである。すじ状の欠点は，抄紙 インではしわ，塗エラインではドクターブレードに起 因する染工すじが問題となる。以前は長いすじが問題 視されていたが，最近では使用目的にもよるが，印刷 用, プリンター用の笁工紙であれば短いスジでも NG となる。中にはシャープで細いスジ，少し太めの輪郭 が不鮮明なスジ，そして斜めのスジもある。

\section{3. 上記課題解決に対する，整社技術の対応}

上記スジに関する課題の解決には複数技術のバラン スのとれた向上が同時に求められる。これらは全てが 揃って最大限の効果が得られる。それらを下記に列記 する。

\section{1 スジ検出に適合した光学系}

基本的に検査システムは正常な部分の光学的特性と 異常な部分の光学的特性の差が大きくなるように光学 系を組む。このように考えると抄秖面は光を抬散反射 させる特性を持っているのに対し，塗装面は，鏡面反 射と拡散反射の中間的な図 1 のような反射配光曲線に なっていると考えられる。

従って抄紙面上のスジ（しわ）は，表面の光学的性 質は良品部分と全く同じであり，見る方向によって見 えたり，見えなかったりする欠点である。しわの凹凸 部による反射光線の角度の変化を捕らえる方式が用い られるが変化量は少なく, 検出の処理が重要になる。 塗工面の慗工ムラによるスジは表面の光沢の度合に応 じて，正反射の成分の大きさが変化するが，微塗工紙 の場合その変化の小さな場合が多くやはり検出の処理

表 1 検出性能の業界差

\begin{tabular}{l|c|c|c}
\hline & \multicolumn{2}{|c|}{ 無地メーカー } & 印刷メーカー \\
\hline ラインスピート & $600 \mathrm{~m} / \mathrm{min}$ & $900 \mathrm{~m} / \mathrm{min}$ & $100 \mathrm{~m} / \mathrm{min} \sim 200 \mathrm{~m} / \mathrm{min}$ \\
\hline 幅分解能 & $0.2 \mathrm{~mm}$ & $0.2 \mathrm{~mm}$ & $0.1 \mathrm{~mm}$ \\
\hline 流れ分解能 2,000 bit カメラ & $0.6 \mathrm{~mm}$ & $0.9 \mathrm{~mm}$ & - \\
\hline 流れ分可能 4,000 bit カメラ & $1.20 \mathrm{~mm}$ & $1.80 \mathrm{~mm}$ & $0.4 \mathrm{~mm}$ \\
\hline
\end{tabular}




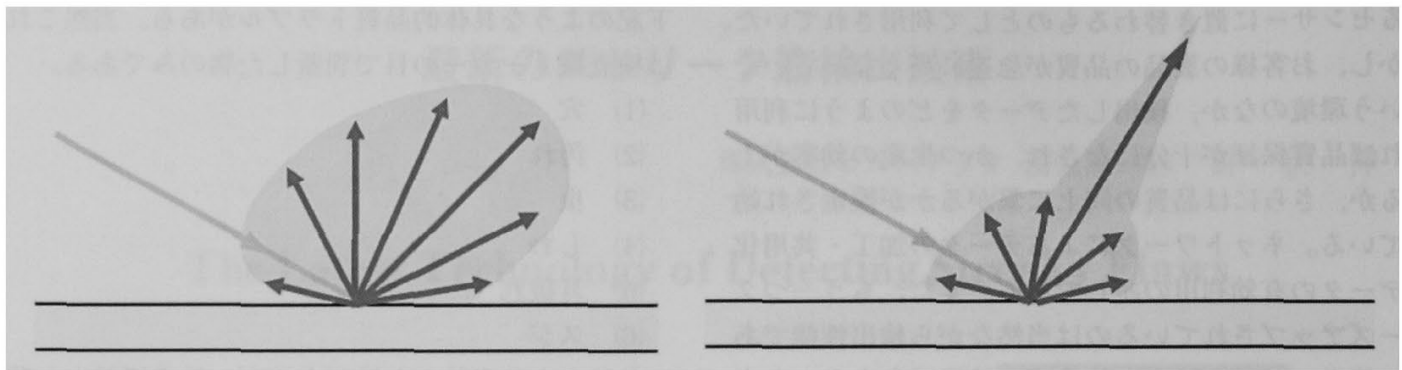

図 1 抄紙面（左図）と塱工面（右図）の反射配光曲線

が重要になる。ただし，表面が更に鏡通に近いコート 紙では大きな変化が得られる場合が多い。

また特殊な例であるが凹凸性の欠陥に対しては指向 性の強い光源によって反射角度の変化を強調させたり, 染工の材質に依存するが, 光の波長域によって変化を 大きくさせる場合もある。

\section{2 レンズの性能}

光のはいる順番でいえば, 光学系の次に, 検出に影 響がでるのはレンスである。このレンズの性能を決め る数值で重要なのが，まず，空間周波数である。これ は，ミリ何本と表現されているが簡単にいうと $1 \mathrm{~mm}$ の間隔で何本の線が認識できるかである。すなわちこ の数値が大きいほどより高精度の検查が可能になる その他に周辺光量, 収差といわれるものは, 空間周波 数も同様であるがレンズの中心から端部までの性能差 を表している。もちろん性能差が小さなものほど高精 度の検査に向いている。ただし，高性能のレンスは高 精度の検查に検査に向いているが最終的には検出とコ ストのバランスになる。

\section{3 カメラの性能}

カメラには CCDの一個のセルの縦横比が $1: 1$ の ものと, 縦の方が長いものとがある。前者は微小欠点 には強いが, コントラストの低いスジの検出には弱く， 後者はコントラストの低いスジには强いが，微小欠陥 には弱いという特徵を持つ。ただし，最近では検出部 の性能も向上してきており前者の CCD でもコントラ ストの低いスジが検出しゃすくなっている。この場合, 効いてくるのがカメラの駆動クロックである。言い換 えれば流れ方向の分解能であり，同じスジを検出する 場合でも早いほうがたくさんスキャンすることになる。 スジには濃度むらがありたくさんスキャンした方が検 出する可能性が高くなるのは当然である。短いスジは 更にいうまでもない。

\section{4 検出部の性能}

ピデオ信号を処理する検出部は複数の要素が含まれる。 検出の前処理から検出の後処理まで含み, やはりどの
部分が久けても検出性能に大きく影響する。

\subsection{1 調 光}

まず，検出性能を維持するには，常に CCDに適正 な光量を与えることが肝要である。確かに処理部にレ ベルの補正機能を有しているが, 光量不足によるコン トラスト低减はカメラで生しるためレベル補正機能で は補えないものである。従って，大きなレベル補正は 調光機能にて行い, レベルの微調を行うのが下記レベ ル補正である。

\section{4 .2 補 正}

入力されたビデオそのままでは，精度の高い検出は できず，レベル補正，シェーディング補正により有効 視野内を同一レベルに均一にする必要がある。検査機 のタイブによってはスレッシュホールドレベルを地合 のレベルにあわせるものもある。

\section{4 .3 複数の検出系}

単一の検出系だけでは不規則な形状, 濃度分布パター ンの多種多粎な欠陥を高い確事で検出することはでき ない。そこで人が恋知すると思える有効な複数の検出 系を並列にして処理する必要がある。これら検出系の 代表的なものを下記に列記し, その中でスジの検出技 術を示す。

1) エッジ強調

この検出系は基本的に，地合信号の中の，コントラ ストのある程度以上の微小な欠点を検出するのに有効 な検出系である。ただし，使用方法によってはスジの 検出にも非常に有効になる場合がある。例えばコント ラストの低い短いスジ，斜めのスジにおいて，部分的 にしか検出できなくても後処理のつながり処理を入れ ることにより微小異物とは判定せずにスジとして判定 することができる（図 2)。

2) 薄污れ強調

この検出系は基本的にある一定面積のコントラスト が低い污れを検出するのに有効な検出系である。前述 したように塗工のスジにはシャープなものもあるが輪 郭が不明確なものもある。この場合当強調处理にて不 

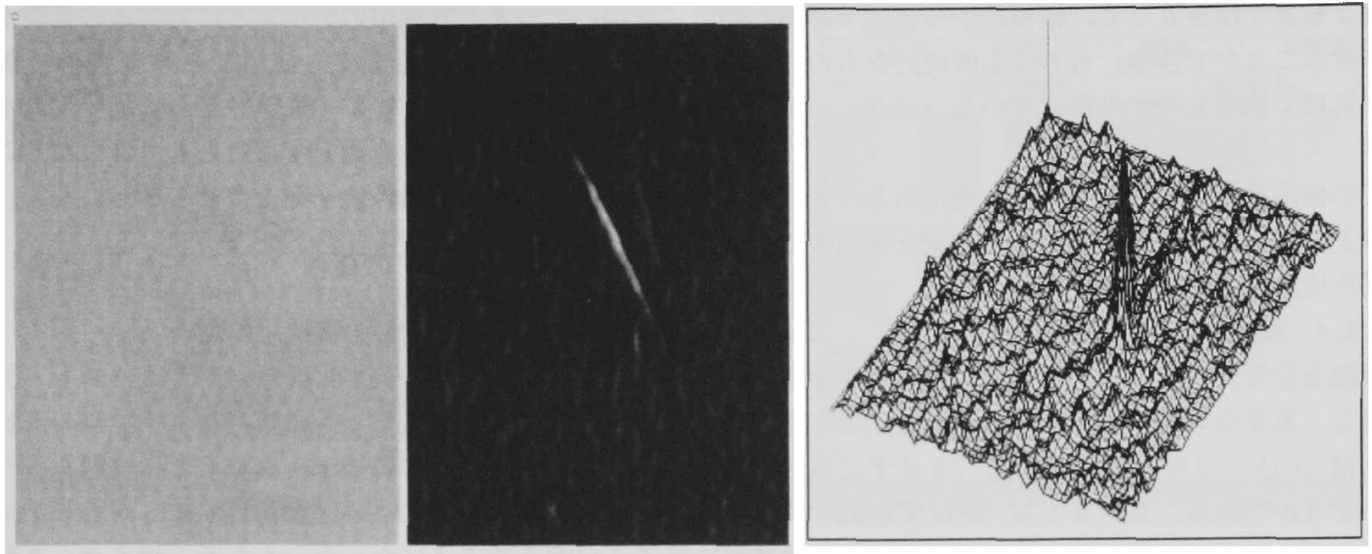

図 2 斜めのスジの検出
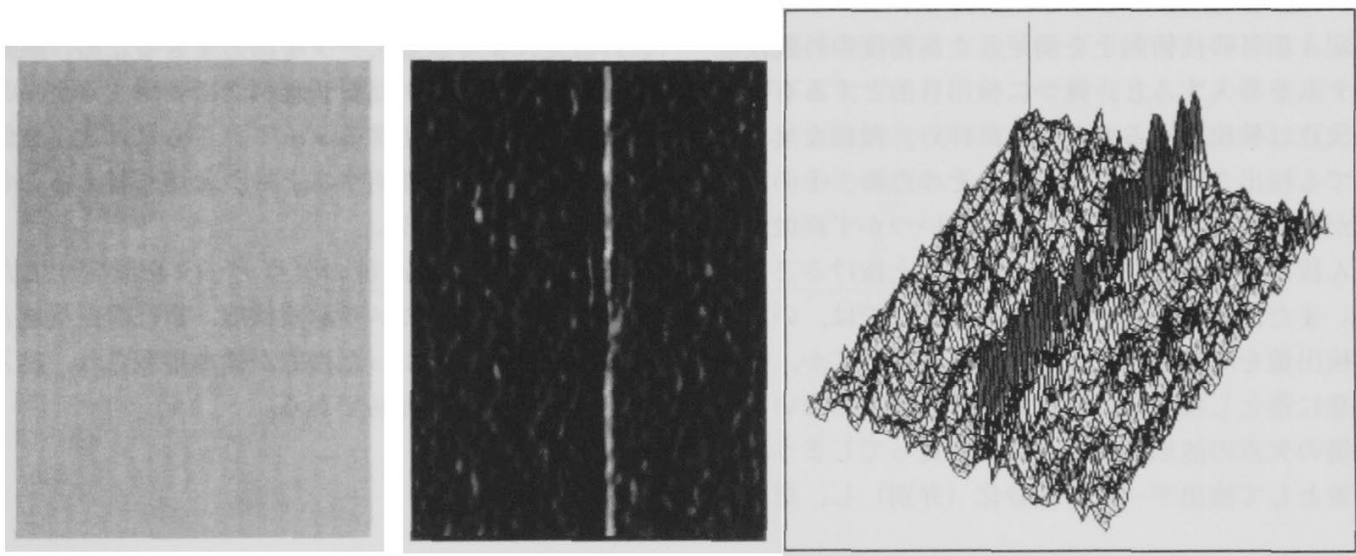

図 3 不鮮明なスジの検出
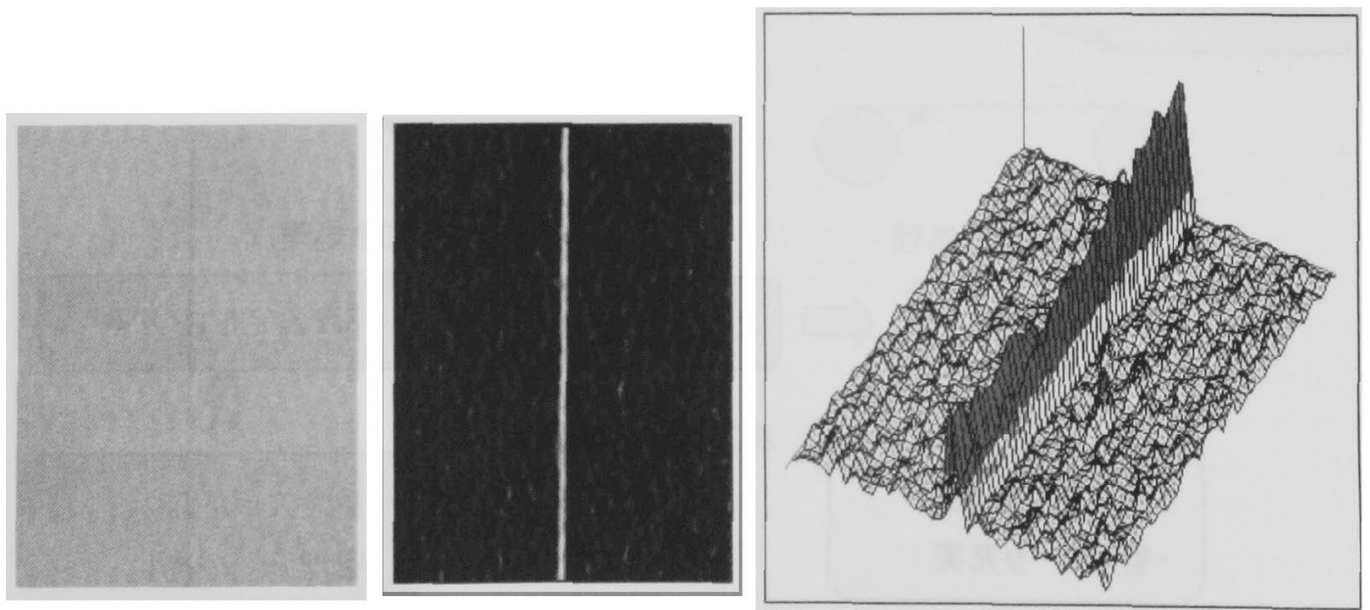

図 4 細いスジの検出 
明確な輪郭を浮き立たせ, 縌横比からスジであると判 定させることができる。もちろん断続的なものもつな がり処理で検出しやすくなっている（図3）。

3) ス ジ強調

この検出系は名前の通り, 基本的にある一定の長さ の以上のコントラストが低い細いスジを検出するのに 有効な検出系である（図 4)。

\section{4 .4 検出部の処理速度}

微細な信号、コントラストの低い細いスジを検出す る場合, 重要なのが信号処理部の速度である。簡単に いえばCCDのセル一個一個を間引きせずに処理でき るかどうかである。カメラが $40 \mathrm{MHz}$ で駆動する場合 は処理側も同じ周波数で駆動させる必要があります。 これは信号を受け検出・計測し，結果をソフトに渡す までである。

\section{5 処理能力}

上記 4 項目の技術向上を満足した高精度の外観検査 システムを導入すると, 確かに検出目的とする有害な 微細欠点は検出できるが, それに伴い, 微細な無害欠 点までも検出されるようになる。そのため，その後の 処理が従来通りであれば，処理が追いつかず画像がた くさん抜けたり，最悪の場合は検出さえ抜けることに なる。また，画像の表示能力が速いだけでは，いたず らに検出数を增加させ次工程の効率を落とすか, 感度 を故意に落とし検查機の性能を十分発揮させないまま 致命傷の欠点の流出というリスクを負ってしまう。こ の対策として検出データを細分化（并別）し, 更に保
証用のデータと管理用のデータとに分ける必要性があ る。この結果, 高感度でも使用でき検查機の性能を 100\% 生かすことになる（図 5)。さらに地合すれすれ にスレッシュレベルを設定することも可能となりこれ もやはりスジの検出性能を向上させることになる。

4.「MaxEye. $P 」 の$ 概要

\section{1「MaxEye.P」の機能・特徵}

当システムは, 各欠点に対し，コントラスト・欠点 サイズ以外にも信号レベルのピーク值や欠点の形状デ 一タといった欠点の特徵データをもとに弁別を行うこ とで，有害・無害欠点の区別が容易にしかもリアルタ イムに行えるようになった。もちろん扱うデー夕量が 膨大になるので画像処理能力も著しく向上しています。 また，当システムでは 100 種の欠点種別・欠点クラス のそれぞれに対し，次点の重要度が設定でき，それぞ れの設定により検查データを出力できるため，製造中 に使用するデータ・品質管理部門で使用するデータ, 品質保証部門で使用するデータ, さらには次工程例え ばリワインダーで使用するデータと切り替えることが 可能となった（図6)。

その他にも, 100 品種の欠点デー夕を設定するため のアシスト機能, カメラ診断機能, 自己診断機能と従 来の検査機にはなかった機能が標準搭載され，納入後 のメンテナンスも容易である。

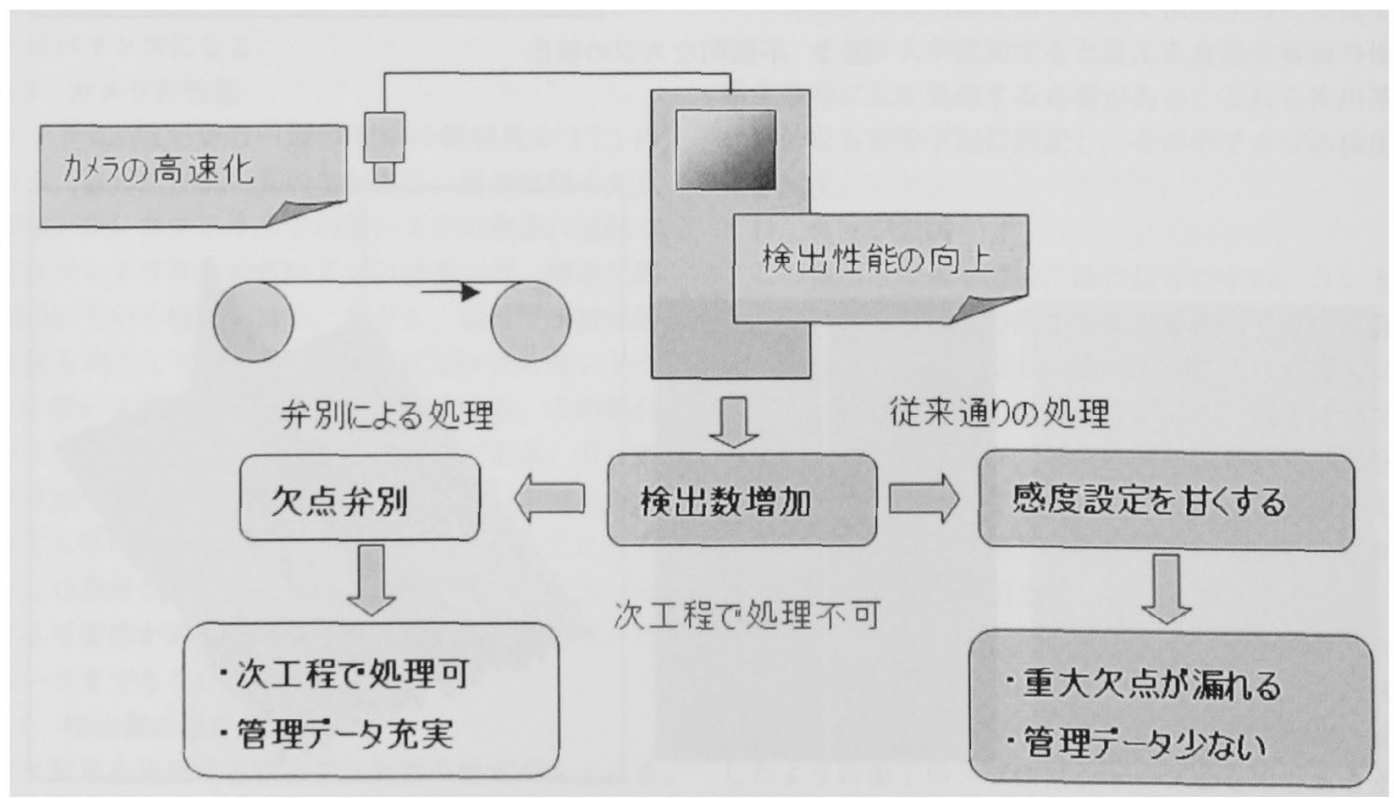

図 5 弁別処理の必要性 

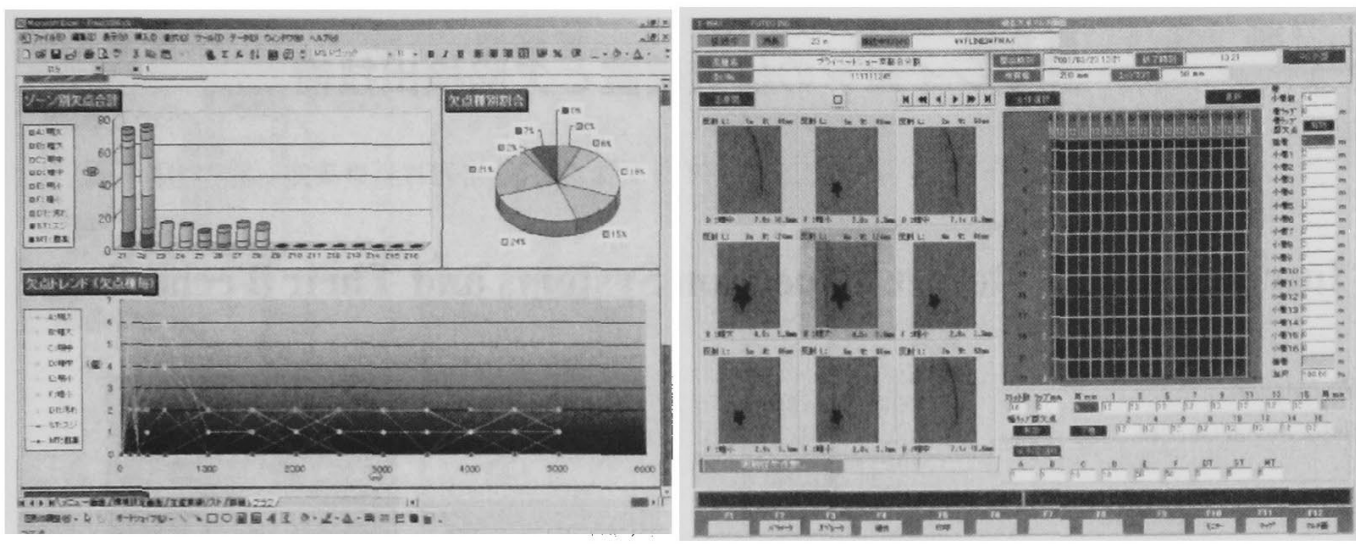

図 6 工程支援ツール

\section{5.おわりに}

動向の激しい産業界において, 検查機導入に当たり, どの期間で，何がしたいか，そしてそれがどのような 効果をあげるかが肝要である。従って, 我々検査機入 一カーも上流, 下流の検查スペック, 市場動向を瞄み
ながら，コンサルティング的な内容を含む製品作り， 提案をしていく必要性がでてきている。そのためには， 導入担当者の方々と我々サプライヤー側のさらなる協 力が不可欠であり，そこで潜在化している要望を顕在 化し, 更に次世代の検查機を生み, 産業界に貢献して いくものと確信している。 
検查システム「iS シリーズ」を低価格で提供すべく開発された検查システムである。「iS シリース」は デジタル画像処理により，同じ検査面を異なる角度の 2 つのカメラで検査し，その2つの欠陷画像から 得られた約 80 種の特徵パラメータにより欠陥を細かく分類でき，さらに金属表面の薄いスクラッチ(ひ っかき疵）を検出するためのストリーク検出アルゴリズムも有している。

「スマート・ビュー」はこれらの機能を継承し, 完全デジタル処理による高精度検出と豊富な特徵量 による欠陥の分類機能が特長である。

本稿では,ストリーク検出機能に焦点をあて，「スマート・ビューICN」の機能を紹介する。

(本文 60 ページ)

\section{最新のストリーク筋検出技術}

東芝ITソリューション株式会社 画像処理応用機器部 藤田稔

ストリーク・筋欠陥は, 細長いといった形状的特徽を有するが, 非常に低コントラストの欠陥である 場合が多い。そこで，欠宿の空間周波数（幅，長さ）注目し，ストリーク・筋に最適化された椱数の欠 宿検出回路を具備した検査装置 M 9000 を開発した。本検查装置によれば, 最適な条件のもとで地合と の S/N 比で 0.25 0.5 程度の低コントラストの久陥が検出可能となる。椱数の検出回路をストリーク 筋に割り当てることができるので，幅広い形状的特徵を持つ欠陥を検出することができる。

これら椱数の久陥検出回路から出力される欠陥デー夕を連結統合することができる。連結統合するこ とにより，ストリーク筋欠宿の実体を表現するより正確な特徽量を抽出することが可能になる。この特 徽量を用いて久陥種類自動判別が実現される。

検出精度が非常に高い検査では，画像入力，前処理および調整サポートッールに，特別な配虑が久か せない。カメラごと, 画素ごとの感度のばらつきを補正する機能, 時間的な入力画像の明るさを一定に 保つ機能など備えられている。また欠宿検出回路ごとにビジュアルに表現される，ピークトレンドグラ フは検査装置が本来持つ性能を発揮するうえで非常に有用な機能である。

(本文 64 ページ)

\section{最新のストリーク筋検出技術}

\section{株式会社ヒューテック 開発部 杉野 欣伸}

今までもそjであったようにこれからも検査システムへの要求は多種多様であり，要求の数もますま す增えていくと思われる。また, 従来㭘査システムを必要としていなかった業界へも拡がりを見せてお ク，気が付けば周辺のとの莱界も最新の検査システムが林立しているという状態になりかねない。この 状態は，日本の製造莱が他と差別化をして生き残るためにさけては通れないものと判断する。この境 下，各業界においてお客様から検査システムに求められる要求内容としては，大きく下記の 2 点がク口 ースアップされている。一つは唡查システムのデータの有効利用です。過去に遡ってみると, 検査シス テムは検査機であり単なるセンサーに置き替わる物として、利用されていた。しかし，お客様の製品の 品質が急速に高くなっていくという環境のなか, 検出したデータをどのように利用すれば品質保証が十 分になされ，かつ生産の奻事が上がるか，さらには品斦の向上に慗がるかが模索され始めている。ネッ トワークによるデータの加工・共用化がデータの有効利用の兆しである。また，もう一つクローズアッ ブされているのは当然ながら検出性能であり，简単にいえば従来の検查機で检出できなかったものも検 出するということである。この検出性能が向上することは前速のデータの加工・共用化にも大きく影静 がありバランスのとれた検查システムには不可欠である。今回はこの検出性能を向上させるための技術 について述べる。

(本文 70 ページ) 